\title{
TP53 NM_000546.5:C.542G>A
}

National Cancer Institute

\section{Source}

National Cancer Institute. TP53 NM 000546.5:C.542 G>A. NCI Thesaurus. Code C162395.

A nucleotide substitution at position 542 of the coding sequence of the TP53 gene where guanine has been mutated to adenine. 